\title{
THE CONCEPT OF FATE IN AMERICAN SCIENCE FICTION LITERATURE
}

\author{
Yana Gryshchenko \\ National Technical University of Ukraine "Kyiv Polytechnic Institute”, Kyiv, Ukraine \\ yanagri13@gmail.com
}

\begin{abstract}
The present article is dedicated to the problem of the concept of fate functioning in the American picture of the world. The aim of the article is to investigate the concept sphere of fate in American science-fiction literature. The main tasks are to outline the main specific approaches to the problem, to analyse synonymic rows of the concept of fate and to form the concept sphere of fate in terms of their characteristics. At the beginning, the outline of the last investigations of the fate was done, and then the historical background of the fate interpretation was introduced. In the next part, the preliminary statistical results of the Fate lexicographical analysis were given. The author tried to prove the material selection with the help of the data from the Corpus of global web-based English and the Corpus of contemporary American English. The practical part of the article is devoted to the analysis of the concept of fate in the American science fiction literature that was done on the basis of the fantastic stories of A.E. van Vogt and E. Mayne Hull. At the result of the analysis the synonymic raw of the fate was formed. At the final part of the article, we made the general conclusion that the concept of fate had such two models of objectification as universal and individual ones.
\end{abstract}

Keywords: concept; fate; destiny; doom; lot; picture of the world; synonymic row.

Introduction. Over the last decades, much research has been concerned with the questions of concepts analysis in various pictures of the world. It should be noted here that the spring of cognitive field was started with the ideas of cognitive psychology by G. Miller (1951), and early research in the field was dominated by the limited number of scholars. At various times the ideas of cognitive linguistics were developed by G. Lakoff and M. Johnson (1980), Ch. Fillmore (1985), R. Langacker (1991). However, the birth of cognitive linguistics was associated with the foundation of the International Cognitive Linguistics Society in 1989 - 1990 years (Evans \& Green, 2006, p. 3).

The actuality of our work could be proved by the fact that the central interest of recent research in the sphere of cognitive linguistics is concentrated on the study of concepts. Different types of concepts are widely investigated by A. Wierzbicka (1992), V.I. Karasik (2001), I.S. Shevchenko (2015).

It stands to mention that understanding the meaning of the word fate requires the detailed look on the concept of fate in the linguacultural picture of the world. In succession to the works by S. A. Ascoldov (1997) and V. I. Karasik (2001) we define the term concept as the multidimensional mental formation that is a substitute for the indefinite plurality of the subjects of one and the same kind in the process of thinking and has such constituent components as conceptual, imaginative and value ones. The determinative component is exactly the conceptual side which differs by the language fixation of the concept, its description, feature structure and comparative characteristics of the concept in relation to another one (Karasik, 2001, p. 9). So, we concentrate our analysis on the conceptual side of the concept. It should also be taken into account, that any concept, and therefore the concept of fate, could be closely dependent on the context, subtext and individual cultural experience of the person.

Aims and tasks. The purpose of our research is to have a look into the concept sphere of fate in American science-fiction literature. The material of the analysis is the fantastic stories by A.E. van Vogt and E. Mayne Hull (Vogt \& Hull, 2002) as the presenters of the genre in American literature. The tasks of the investigation are to outline the main specific approaches to the problem, to analyse synonymic rows of the concept of fate and to form the concept sphere of fate in terms of their characteristics.

Theoretical background. The concept of fate is in the raw of the basic concepts in literature. One of the first linguistic investigations of the concept of fate was carried out by A. Wierzbicka (1991) and N.D. Arutjunova (1994). A. Wierzbicka (1992) proposed the comparative analysis of the Polish concept Los and Russian concept Sud'ba. There were also the parallel studies of the fate synonymic rows in French, German and English pictures of the world. The scientist came to the conclusion that the meaning of the concept of fate depends on the specific peculiarities in the national context, philosophy of life and cultural history of the nation. N. D. Arutjunova (1994) contrasted fate and truth and considered fate as a group of terms that are the interpretation of the people's life (p. 302). 
Nowadays, a lot of works are dedicated to the fate investigations. Active studies of the concept of fate were carried out in Arab picture of the world (Cohen-Mor, 2001; Salih, 2002), where fate is the synonym of God's will. Time, fate and doom in Germanic paradigm were investigated by O.V. Trots (2008), A. Winterbourne (2004) and J. Richard Witt (2010). There are several historical studies of fate by modern scientists (Bröndsted, 2014; Eidinow, 2011). In Slavic linguistic tradition the objects of the fate research are substantially concentrated on the Russian and European pictures of the world (Abaeva, 2007; Andreichuk \& Mamazhanova, 2007; Forofontova, 2009; Gryshchenko, 2014). The materials of such studies include both poetry and prose. However, the study of the fate in Slavic poetical discourse is the most extensively studied area (Ivanona, 2013; Kalashnyk, 2011; Masenko, 2014; Suhova, 2014). It is important to know though, that the fate in the field of science-fiction literature is not clearly analysed. The novelty of our research is the fact that the investigation of the fate in American picture of the world was done on the basis of the fantastic stories of A.E. van Vogt and E. Mayne Hull (Vogt \& Hull, 2002) which we associate as the quintessence of American science-fiction literature.

Historical background. Fate is an individual development pattern in the course of the lifetime. It is a course of events or a set of circumstances that is beyond the control of the person. Fate is one the most mysterious beginnings of our life. In ancient mythology, it was believed that fate is a pour of everything. Fate is an eternal enigmatic truth that occupies the attention of poets, writers and scientists. Fate as an uncontrollable state has always drawn writer's attention.

In prehistory times, the Fates of Greek and Roman religion and mythology were inexorable. One has only to think about the Moirae and the Parcae who were adamant to entreaties. In ancient Greece, the Fates (the Moirae) are represented as three old women, and their allotting of fate as a process of spinning, measuring and cutting a thread. Clotho spins the thread, Lachesis determines its length, and Atropos cuts it off when the time comes. In Roman culture thought the Fates (the Parcae) are often the impersonally conceived Fatum. But in Greek mythology, there were positive contrasts to the inevitable Fates. Tyche (Luck or Fortune) and Ananke (Necessity) are the concepts closely related to fate (Kirkwood, 1995, p. 43). That particular understanding of fate became one of the early interpretations of fate that is commonly found in present American picture of the world. For another thing, as specified in the work of C. Gay, J. Hochschild \& A. White (2016) modern Americans still believe in linked fate.

Preliminary analysis. According to the preliminary statistical study on the basis of English lexicographical and literary sources, it was formed the synonymic raw of the English picture of the world. The raw consists of such eight elements as fate $\rightarrow$ chance $\rightarrow$ destiny $\rightarrow$ doom $\rightarrow$ luck $\rightarrow$ lot $\rightarrow$ providence. Every element has a special shade of meaning which is dependent as from the dictionary's definition as from the context. For example, fate forces could be 1) good (fortune, fate) or evil (fortune, destiny, fate, doom, lot); fate could express 2) risk (fortune, luck, fate, chance), 3) predestination, inevitability (fate, destiny, doom); 4) opportunity, fortuitous event or fortuitous combination of circumstances (chance, fate, fortune, lot, luck); 5) foresight, force predetermining the development of life (providence, the stars, lot); 6) unhappy, cruel fate (luck, lot) (Gryshchenko, 2014, p. 624).

In English literature from the second part of the $20^{\text {th }}$ century understanding of the fate was various in different genres of literature. According to the Corpus of global web-based English (GloWbE, 2012-2013), the majority of the fate entrances are concentrated in the American (8080 items) and British (7765 items) discourse. Since the American corpus is a leader we deem it expedient to focus on it. In light of the Corpus of contemporary American English (COCA, 1990-2015) the most numerous usage of the fate is in the area of fiction (3398 items). Science fiction literature as sub-genre of the fiction one is the source of 789 fate items. Thus, science fiction literature is the favourable material for the concept of fate studying.

Factual material analysis. Some of the prominent writers in the field of science fiction American literature of the $20^{\text {th }}$ century are A.E. van Vogt and E. Mayne Hull (Vogt \& Hull, 2002). Such their stories as The Timed Clock, The Ghost, The Wishes we make, The Ultimate Wish are the quintessence of the fate literary functioning. The works of the authors are notable for the place of the fate in the stories composition. The stories are stands out for their ingenuity of the plot, exact psychological development of the heroes' characters, richness and expressiveness of the language.

Despite on the definite plots' unreality in all stories, real life situations with their eternal struggle of opinions, wishes and goals are noticeable. The concept of fate is found in each of their 
works, but not always it is possible to see it on the surface of the story. For the matter of that, the differences in the stories of A.E. van Vogt and his wife are obvious.

If the concept of fate in A.E. van Vogt works can be mainly detected at the level of subtext, in the work of E. Mayne Hull we have an opportunity to find this concept almost on every page.

If for example, we read the story The Timed Clock by A.E. van Vogt's, we find the ordinary, standard use of the word fate in its literal sense, without any connotations:

"I am sure that everything will be all right. The fate cannot laugh at me." (Vogt \& Hull, 2002, p.54)

In this case, the semantic meaning of the concept of fate is the road that this character ought to pass, his future story with the storybook ending.

In the context of the second story The Ghost by A.E. van Vogt it should be mentioned that, in the same way as for the previous story, the concept of fate is found quite rare. However, it occurs in more mysterious context and indirect meaning.

"You're not trying to tell me that the ghost also tells the future. Why, today's only July $8^{\text {th }}$, and I intend to stay till the end of September.” (Vogt \& Hull, 2002, p.16)

It should be noted that the word future that was mentioned in the example is the indirect synonym for the word fate. In this case, it confirms the fact that the concept of fate has a majority of variations and additions within a certain literary context.

As for the existence of the concept of fate in the subtext, both works of A.E. van Vogt are characterized by such peculiarity, which is dependent on the momentary context and the individual perception of the reader.

In contrast to A.E. van Vogt stories E. Mayne Hull often uses the word fate in their stories, but, in the same way as for the previous author, she lays stress on the subtext. Her story The Wishes we make abounds in synonymous raw of the fate. Here we can found such synonyms as fate, destiny, doom and fortune. However, the most commonly used ones are fate and destiny. In addition, in this story each step of the main character is predetermined by fate, even if it is not said unequivocally. Like the main character's name, the word fate is written with a capital letter. Throughout the story the main character is trying to escape or change his fate, but the latter finally overcomes him. In this story the fate is not something abstract, it is embodied in the creature of $D r d r$. It is capable of carrying out six wishes of the character. However, all the wishes are strictly limited by the Fates. It appears that the fate is unavoidable but $D r d r$ can manipulate within the bounds of this inevitability.

Within the limits set by the Fates, of course. (Vogt \& Hull, 2002, p.126)

It was Drdr hands, with the help of which E. Mayne Hull put her conception of the fate into life and pretended to be a hero trying to save the main character from the inevitable fate. Thus, we can assume that it was the fate that comes to the fore of the story.

There are numerous examples that illustrate the aforesaid view on the use of the concept of fate in the story The wishes we make by E. Mayne Hull.

What do you mean, limits set by the Fates? (Vogt \& Hull, 2002, p.128)

In this case, the fate expresses the idea of predetermination and uncertainty. This fate fatally comes true. Nobody can avoid it by any means.

Your destiny cannot be changed. (Vogt \& Hull, 2002, p.128)

As in the previous case, the main semantic meaning of the concept of fate is inevitable. Destiny is associated with the life journey that befalls a person or caused by the circumstances, laws of society and nature.

Every man has his predestined fate. It is inexorable, and in your case the situation is that wishes will do you no good. You are doomed to die by hanging. (Vogt \& Hull, 2002, p.128)

In this context, the negative connotation of the fate is shown. The synonymic raw includes fate and doom. At this point, the fate means the unfortunate result of people's life.

The other examples of the predetermined cruel fate are shown in the aforesaid terms of the fate and destiny.

Everything is taking place as fated. ... But it was simply the victim's destiny. (Vogt \& Hull, 2002, p.158)

"My destiny is fulfilled. ... and I, in the body of Pearsall, go on." 
The red eye fixed on him unwinkingly. "Only one thing is wrong: Pearsall is not destined to hang." (Vogt \& Hull, 2002, p.160)

In this case, E. Mayne Hull contrasts the fate and destiny of the condemned prisoner with the destiny of the ordinary person.

Yet another reflection of the negative unavoidable side of life is shown in the next examples.

See what I'm getting at: No swindle, no murder, no destiny. No one, came the calm reply, can escape his destiny. (Vogt \& Hull, 2002, p.138)

Accordingly, you went back into time, re-enacted the murder and the trial, and here you are, facing your inevitable destiny. (Vogt \& Hull, 2002, p.140)

In the first example, the hero associates the word destiny with swindle, murder and reiterates the meaning of the fate's inevitability. In the second example, it is proved that destiny has the meaning of ill fate.

You are you, a definite pattern in the universe, with assigned role. You cannot be different. The Fates made you as you are. (Vogt \& Hull, 2002, p.144)

If I were different I might develop some screwy religious notion about accepting my fate. I guess I can handle this best as myself. (Vogt \& Hull, 2002, p.144)

In these situations, the word fate is used in the neutral direct meaning and forecasts all that a person overcomes in life.

Thus, the meaning of the fate varies from the neutral shade to the sad one. There is no positive connotation of the concept in the story. The concept sphere of the fate is limited by such synonymic raw as fate $\rightarrow$ destiny $\rightarrow$ doom.

The second analysed story by E. Mayne Hull is The Ultimate Wish. This story is also full of the fate entries. However, in the same way as for the A.E. van Vogt stories, E. Mayne Hull hides the concept but gives the reader an opportunity to find it among the lines. There are only to direct entrances of the fate in the story, and both of them are used in direct meaning.

"Well, then," shrugged the witch, "what about the opposite of revenge: Remember, you are one of Nature's botches, one of Nature's attempts at something different and better. No one is to blame. Your best wish, therefore, would perhaps be one that would make your contented with your lot. Would you like that?” (Vogt \& Hull, 2002, p.228)

In this case, the fate takes the meaning of lot. This synonym to the word fate is used in the meaning of the road to the future.

The thing was suddenly as clear as glass. If there were such a wish-and the creature had reluctantly admitted there was - then it was the only possible wish. All the others were mutilations, miserable affair entailing some tremendous sacrifice in exchange. But the ultimate wish! Well, ultimate meant - ultimate! She had a sudden high sense of destiny! (Vogt \& Hull, 2002, p. 230)

In this example, the fate is shown as destiny which steps forward and means a kind of the flash of insight as for the future life.

Taking into account all the aforesaid analysis of the science fiction stories by A.E. van Vogt and E. Mayne Hull along with the data of the preliminary statistical analysis in lexicographical sources we came to the conclusion that the most widespread, comprehensive and appropriate for the analysis of such kind are fate, destiny, doom and lot. It should be noted that the synonyms differ due to the additional characteristics that they share.

1). Fate has the widest meaning and covers all that a person's experience in life.

2). Destiny is associated with the life journey that befalls a person or caused by the circumstances, laws of society and nature.

3). Doom has strictly negative connotation and means the unfortunate end of people's life.

4). Lot is the future road that the person ought to pass.

Conclusion. It is important to note that the concept of fate can be shown not only on the surface of the composition when it verbalised in the line of synonyms but also among the lines. This assertion entirely corresponds to the characteristic features of the concept and the essence of the concept of fate that were mentioned at the beginning of the article.

The stories by A.E. van Vogt and E. Mayne Hull as the samples of the American science fiction literature are the illustrations for the two models of the fate. The first one is universal (birth $\rightarrow$ 
life $\rightarrow$ death), the second is individual (life journey). The stories by A.E. van Vogt are related to the individual model while E. Mayne Hull uses the universal one.

Thus, the future investigations of the fate in the field of American science fiction literature ought to be based on the two distinguished models together with the definite synonymic raw (fate $\rightarrow$ destiny $\rightarrow$ doom $\rightarrow$ lot). The perspective of the further research is in the broadening of the material of the analysis and pursuance of the comparative study of the concept of fate in different genres and discourses.

\section{References:}

Abaeva, E.S. (2007) Lingvokul'turologicheskij aspekt koncepta "sud'ba" v anglijskom, russkom i francuzskom jazykah [Linguocultural aspect of the concept of fate in English, Russian and French pictures of the world]. Extended abstract of PhD thesis, Moskow, Russia.

Andreichuk, N.I. \& Mamazhanova, I.A. (2007). Deiaki osoblyvosti verbalizatsii kontsepta "dolia" v ukrainskii ta anhliiskii movakh [Some peculiarities of the concept of fate verbalization in Ukrainian and English languages]. Visnyk natsionalnoho universytetu "Lvivska politekhnika". Problemy linhvistyky naukovo-tekhnichnoho $i$ khudozhnoho tekstu ta pytannia linhvometodyky, 586, 47-52.

Arutjunova, N.D. (1994). Istina i sud'ba [Truth and fate]. In N.D. Arutjunova (Eds.) Ponyatie sud'by v kontekste raznyx kul'tur (pp. 302-316). Moscow, Russia: Nauka.

Askoldov, S.A. (1997). Koncept i slovo [Concept and word]. In V.P. Neroznak (Eds.) Russkaya slovesnost'. Ot teorii slovesnosti k strukture teksta (pp. 276-279). Moscow, Russia: Academia.

Bröndsted, M. (2014). The transformations of the concept of fate in literature. Scripta Instituti Donneriani Aboensis, 2, 172-178.

Cohen-Mor, D. (2001). A Matter of Fate: The Concept of Fate in the Arab World as Reflected in Modern Arabic Literature. New York: Oxford University Press.

Eidinow, E. (2011). Luck, Fate and Fortune: Antiquity and Its Legacy (Ancients and Moderns). London: I.B. Tauris.

Evans, V. \& Green M. (2006) Cognitive Linguistics: An Introduction. Edinburgh: Edinburgh University Press.

Fillmore, Ch. (1985). Frames and the semantics of understanding. Quaderni di Semantica, 6, 222-254.

Forofontova, Yu.L. (2009). Koncept sud'ba i ego yazykovaya reprezentaciya v diskurse [The concept of fate and its language representation in discourse]. Unpublished candidate dissertation, Tambovskij gosudarstvennyj universitet imeni G.R. Derzhavina, Tambov, Russia.

Gay, C., Hochschild, J. \& White, A. (2016). Americans' Belief in Linked Fate: Does the Measure Capture the Concept? The Journal of Race, Ethnicity, and Politics, 1, 117-144. http://dx.doi.org/10.1017/rep.2015.3

Gryshchenko, Ya.S. (2014). Sud'ba kak lingvokul'turnyj marker russkoj i anglijskoj kartin mira [Fate as the linguacultural mark of Russian and English pictures of the world]. Molodoj uchenyj, 7 (66), 623-625.

Ivanova, N. (2013). Dolia-Rezhyser, Dolia-Pozykodavets i Dolia-Suddia u tvorakh M.Yu. Lermontova [The fate-the Director, the Fate-the Creditor and the Fate-the Judge in the works of M.Yu. Lermontov]. Vcheni zapysky Tavriiskoho nats. universytetu im.V. I. Vernadskoho. Ser: Filolohiia. Sotsialni komunikatsii, 26(65), 1, 478-482.

Johnson, M. \& Lakoff, G. (1980). Metaphors we live by. Chicago: The University of Chicago Press http://dx.doi.org/10.7208/chicago/9780226470993.001.0001

Kalashnyk. V.S. (2011). Kontsept "dolia" v poetychnii kartyni svitu Tarasa Shevchenka [The concept of fate in the poetry picture of the world by Taras Shenchenko]. Liudyna ta obraz u sviti movy : vybrani statti, 175-179.

Karasik, V.I. (2001). O kategoriyax lingvokul'turologii [About the categories of linguoculturology]. Yazykovaya lichnost': problemy kommunikativnoj deyatel'nosti, 3-16.

Kirkwood, G.M. (1995). A Short Guide to Classical Mythology. Wauconda, IL: Bolchazy-Carducci. http://corpus.byu.edu/glowbe/help/intro_e.asp? $\mathrm{w}=\& \mathrm{~h}=$

Langacker, Ronald W. (1991). Concept, Image, and Symbol: The Cognitive Basis of Grammar. Berlin: Mouton de Gruyter. http://dx.doi.org/10.1515/9783110857733

Masenko, L. (2014). Kontsept dolia v poezii T. Shevchenka u zistavlenni z polskym los i rosiiskym sudba [The concept of fate in the poetry by T. Shevchenko in comparison with Polish los and Russian sudba]. Ukrainska mova, 4, 3-11.

Miller, G.A. (1951). Language and Communication. New York: McGraw-Hill. http://dx.doi.org/10.1037/11135-000

Salih, Sabah A. (2002). The Committee / A Matter of Fate: The Concept of Fate in the Arab World as Reflected in Modern Arabic Literature / the Last Summer of Reason. The Middle East Journal, 56, 3, 512.

Shevchenko, I.S. (2015). Koncept kommunikativnogo povedenija i zhanr [The concept of the communications behavior and genre]. Zhanry rechi, 1, 11, 23-29.

Suhova, A.V. (2014). Reprezentaciya koncepta sud'ba v tragedii M. Cvetaevoj "Ariadna" [Representation of the concept of fate in the tragedy by M. Cvetaeva]. Fundamental'nye issledovaniya, 3, 658-662.

Trots, O.V. (2008). Verbalization of the Concept FATE in old Germanic Languages: Ethno-cultural Aspect. Unpublished candidate dissertation, Kyivskyi natsionalnyi linhvistychnyi universytet, Kyiv, Ukraine.

Vogt, van A.E \& Hull, Mayne E. (2002). The wishes we make and other stories. Moscow, Russia: Astrel.

Whitt, Richard J. (2010). Germanic Fate and Doom in J.R.R. Tolkien's the Silmarillion. Mythlore, 29, 1/2, 115-129.

Wierzbicka, A. (1992). Semantics, culture, and cognition: Universal human concepts in culture-specific configurations. Oxford: Oxford University Press.

Winterbourne, A. (2004). When the Norns Have Spoken: Time and Fate in Germanic Paganism. Madison, NJ: Fairleigh Dickinson University Press. 